\title{
China in Africa: Does history repeat itself?
}

By Jean Raphaël Chaponnière

Asia Centre, Paris

Once upon a time, an emerging Asian economic power made inroads on African markets. The entry of this newcomer aroused a flurry of criticisms from established European merchants. They claimed that this competition was unfair as it employed cheaper labour who toiled far longer hours than Europeans. Not only did this intruder base its competitiveness on the undervaluation of its currency but its financial practices were disloyal as it proposed three year maturity loans while established exporters offered a three month revolving credit. Last but not least, it infringed copyright. This issue was raised by Lieutenant Commander Astbury at a meeting of the House of Commons on November 1933. There, he showed to the assembly a pattern of cloth which had been sent from Manchester to South Africa at 33d. per yard and a copy of that same pattern which was sold at 19d. per yard. He then declared "How on earth can we meet that devastating competition? Within six months after we put a new pattern into the market that pattern is copied and a similar cloth is offered by this Asian competitor at a price which is 75 or 100 per cent below (..). What hope is there for the Lancashire cotton trade unless that competition is stopped?"1

These criticisms sound familiar to the reader as there are now used against China. The criticised new competitor in the 1930s, however, was Japan.

Japan's entry in Africa started at the end of the $19^{\text {th }}$ century and its exports surged after the Great Crisis (see part 1 of this article) and there are some interesting parallels to the $21^{\text {st }}$ century rise of China in Africa. Japan's relations with Africa went beyond trade as illustrated by its special relationship with Ethiopia (see part 2). And as the emergence of this new power challenged Western historical domination, Japan was considered as a model by some African countries (see part 3).

17 Today the irruption of China into Africa is sometimes perceived as an exotic illustration of globalisation. However, Asia and Africa relations predated the arrival of Western powers.

\section{Japan and Africa}

Today the eruption of China into Africa is sometimes perceived as an exotic illustration of globalisation. However, Asia and Africa relations predated the arrival of Western powers as the Indian Ocean had been the main trade link $^{2}$ between these two continents. In a book written between 20 to 40 BC ("The Periple of the Erythrea Sea"), a Greek trader based in Egypt described the Indian merchant activity on the East coast. The kingdom of Askum (former Ethiopia) was engaged in international trade with the Roman Empire, China and India. Further south, Malays reached the island of Madagascar in the $7^{\text {th }}$ century. Between the $13^{\text {th }}$ and $14^{\text {th }}$ century the Zimbabwe kingdom participated in a comprehensive trade network and discoveries of Chinese porcelains are a testimony of the trade between China, South East Asia and Africa. According to F. Braudel, by the $15^{\text {th }}$ century East Africa belonged to a world economy centred on India. Around 1421 China made a brief appearance as the armada of Admiral Zheng He visited several East 
African countries. When the admiral sailed back to China, a new emperor had closed the country.

While the records of Japan's contacts with Africa during the pre-Meiji era are fragmentary (Agbi Olu 1992), they can be traced back to the $16^{\text {th }}$ century. There were no further contacts as Japan chose to insulate itself after the failed invasion attempt by the Mongols and those who violated the prohibition were punished with the death penalty. By the mid- $19^{\text {th }}$ century, the defeat of the Chinese convinced Japan to accept American Commodore Oliver Perry's edict and to open the country. Launched by the imperial restoration (1868), industrialisation gave Japan the means to conquer Asia. After its victory over China (1895) by which it gained Taiwan, Japan destroyed the Russian fleet at Tsushima (1905) and conquered Korea.

\section{While the records of Japan's contacts with Africa during the pre- Meiji era are fragmentary, they can be traced back to the 16th century.

During the second half of the $19^{\text {th }}$ century, Japanese travellers began to call on African ports en route to Europe and to Brazil ${ }^{3}$. Late-comers to the colonial adventure, Japanese were interested in the military lessons they could draw from wars (in South Africa and Ethiopia) and also in the Western experiences in managing colonies. In 1897, Dr. Tomizu Hirondo, a professor of law at Tokyo Imperial University and an admirer of Cecil Rhodes, published a short pamphlet (The Future of Africa) where he forecasted that Africa and China would become major actors in the $20^{\text {th }}$ century (Aremu Fatai Ayinde, 2009). He advised his government to participate in the scramble for Africa before Europeans completely controlled the continent. While the government did not heed his advice, the administration made efforts to gather information on Africa (Katsuhiko Kitagawa, 1990). In 1903, having spent two months in South Africa, the Japanese consul in Singapore and an official of the Ministry of Agriculture and Commerce published the first report on an African country ${ }^{4}$. In 1917, the same minister published a report on the foreign trade of South Africa and investigated the possibility of sending Japanese migrants; it admitted that SA immigration laws would represent a major hindrance to the development of trade.

During World War I, commercial information was collected by Japan's honorary Consul in Cape Town and after the war, consulates were opened in Mombasa (1932), Addis Ababa and Casablanca (1936) and legations in Cairo (1936) and Cape Town (1937). A 1932 British foreign office memorandum stated that at a time when almost all of Africa was under colonial rule, the Osaka Chamber of Commerce and Industry organised an All Africa commercial exhibition (Kweku Ampiah, 1990). The gathering of this information proved to be helpful for the promotion of Japanese exports to Africa.

Up to the end of the $19^{\text {th }}$ century, Japanese overseas trade had been handled by European and Chinese merchants but by 1905, large Japanese trading companies had established trade relations with Europe, North America, Australia and British India while small and medium merchant houses handled trade with Asia, the Middle East and Africa. During World War I, the disruption of trade between Europe and Africa offered a window of opportunity for Japan to enter the British African colonies since Britain had adopted an open door policy in place of the old system of imperial preferences. Even if some protectionist measures were taken during the 1930s, East African colonies remained open to free trade (Kweku Ampiah, 1990). 
Figure 1: Japanese exports to Africa (1896 - 2010)

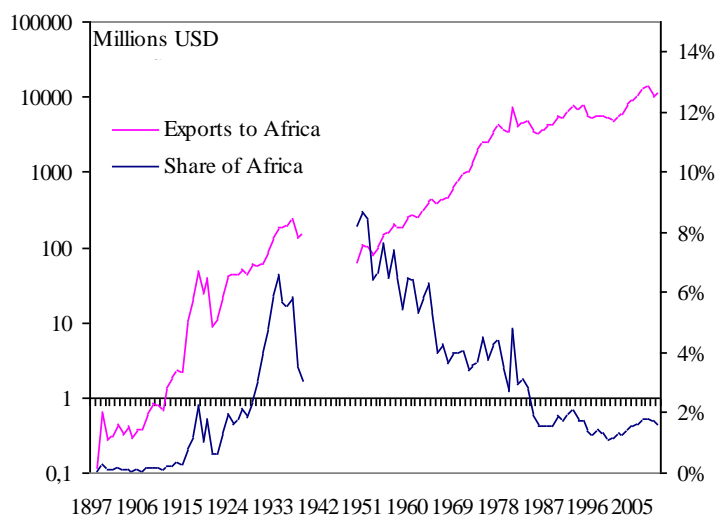

Figure 2 : Japanese imports from Africa (1897 - 2010)

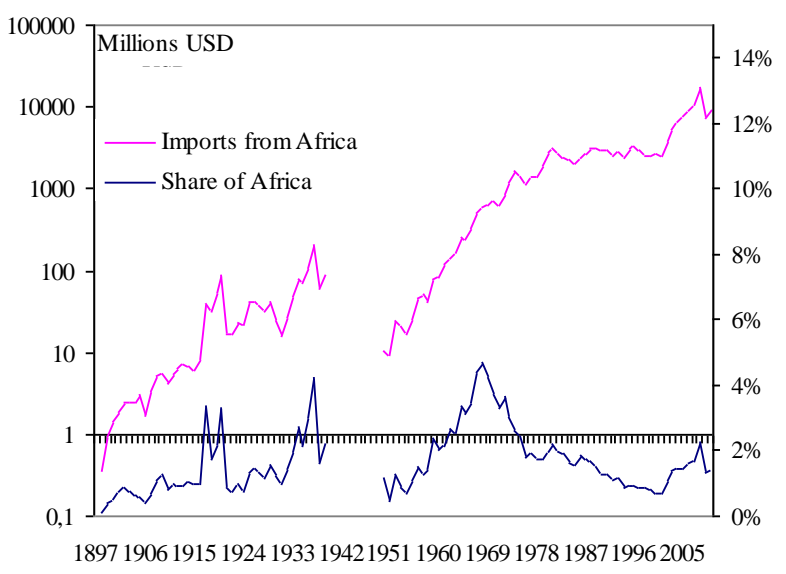

Sources: 1890-1940 : Shionoya, Y., Yamazawa, 1973; 1950 to 2010 : IMF direction of Trade Statistics

\section{Japanese exports to Africa flourished during WW1; and while they decreased after their wartime boom, they still remained greater than their pre-war value.}

Japanese exports to Africa flourished during World War I; and while they decreased after their wartime boom, they still remained greater than their pre-war value (Figure 1). In the 1920s, the falling cost of cotton thread and the abolition of the gold standard in 1931 which diminished by 50 percent the value of the Japanese yen against the pound, gave a strong impetus to Japanese exports. In the meantime, the drop in commodity prices caused by the crisis reduced the ability of British colonies to import manufactured products and encouraged them to turn more towards Japanese products. The Economist ( 3 January 1925) wrote that Japanese low priced products are appreciated by "the natives who put cheapness above quality (..) British machinery holds its own as do British goods of high quality but cheap cottons come from Japan, America and India". Between 1927-1929 and 1936-1938, Japan's share in the imports of Britain's African colonies (Egypt and South Africa excluded) grew from 1.6\% to $7.9 \%$ in spite of the quotas imposed on them by Nigeria and the then Gold Coast (today's Ghana).

Textiles represented a significant share of Japanese exports to Africa. From 1927 to 1929, Lancashire firms were shaken by the surge of Japan's textile market share while Indian exports also shrank. Japanese competition in West Africa was not as serious, as the British colonies had imposed quotas, and French colonies had kept to the imperial preference. 


\begin{tabular}{|l|c|c|c|c|}
\hline \multicolumn{5}{|c|}{ Table 1 :Share of Japanese imports } \\
\hline & British colonies & $\begin{array}{c}\text { French } \\
\text { colonies }\end{array}$ & $\begin{array}{c}\text { Portuguese } \\
\text { colonies }\end{array}$ & $\begin{array}{c}\text { Belgian } \\
\text { colonies }\end{array}$ \\
\hline $1911-13$ & $1,6 \%$ & & & \\
\hline $1927-29$ & $7,9 \%$ & $4,9 \%$ & $0,6 \%$ & \\
\hline $1936-38$ & $7,8 \%$ & $2,1 \%$ & $4,5 \%$ & $15 \%$ \\
\hline $1970-71$ & $3,8 \%$ & $2,5 \%$ & & \\
\hline
\end{tabular}

Source: Bouta Etemad (2005)

1 In South Africa, the surge of Japanese exports led the government to a tariff reform, the adoption of protective measures and legislation prohibiting Japanese from residing and doing business.

In South Africa, the surge of Japanese exports led the government to a tariff reform, the adoption of protective measures and legislation prohibiting Japanese from residing and doing business (Richard Bradshaw, Jim Ransdell 2011). Nevertheless, as South African exports felt the pinch of the crisis, the government allowed Japanese wool purchasers to enter the country. A gentleman's agreement (October 1930), allowing a one year visa to Japanese was strongly criticized in the press which denounced a predicted invasion of retail traders and employees and of Japanese "spying out the land". It was strongly felt in the textile and in the shoe industries: "plimsolls were selling at one third the price of local hide shoes", and, according to an issue raised in the House of Commons ${ }^{5}$, Japanese traders were dumping motor cars into South Africa with British names!

In the 1930s, Japanese were often accused of selling "watches by the kilo" and, this could explain why, some years after World War II, the "made in Japan" label has remained synonymous with low quality goods in East Africa as well as in Morocco where Japan was its second largest exporter (well behind France).

\section{Beyond trade: Japan's special relationship with Ethiopia}

The relations between Japan and Ethiopia went beyond trade. Both countries were Empires ruled by very old dynasties. Like the Japanese, the Ethiopians first admitted the Portuguese in the $16^{\text {th }}$ century when it suited them and both abandoned their attempt to live in a hermit kingdom in the $19^{\text {th }}$ century and acquired Western military techniques. In April 1896, the Japanese Ministry of Defence wished to send three observers to follow the Italian campaign in Ethiopia. This request was rejected by Italy who had suffered a serious military defeat at the battle of Adowa in March 1896. Consequently, Ethiopia enjoyed some prestige in Japan. (The first victory of a nonwestern nation was followed nine years later by the Japanese victory over Russia). At the occasion of the first Japanese official visit in 1927, a draft proposal of a Friendship and Trade treaty was discussed (Hideko Faërber 1998). This treaty was signed three years later when Japanese representatives attended Haile Selassie's coronation. In the wake of this signature, Japanese government representatives as well as private entrepreneurs visited Ethiopia to explore commercial and political ties. By 1930, Japan was the largest exporter to Ethiopia and it took the lion's share of Ethiopian imports of textiles ${ }^{6}$. 
Among the Japanese visitors, some dubious characters also emerged. On 21 September 1933, the London Daily Herald wrote that Ethiopia gave a lease of 1.3 million acres of farmland for the cultivation of cotton to the Nagasaki Association for Economic Investigation and that it had agreed to grant a monopoly for raising opium poppies. This accord had led to the establishment of an emigration company capable of sending 650000 settlers according to the Far Eastern survey (January 1935). Six months later, the same review wrote that cotton and poppy growing suggestions as well as the arrival of Japanese colonists had not been substantiated.

Even though the deal had not been signed, this information snowballed. A Japanese newspaper wrote that Ethiopia would become a new Brazil ${ }^{7}$. In France in December 1933 Le Temps $^{7}$ wrote that, while Tokyo and Addis had rejected the cotton project, Ethiopia had not denied that it wished to promote Japanese investments and that such hostility towards European economic interest called for an energetic response from Italy. Le Temps and the Italian Azione coloniale published worried comments about the possibilities of a Japanese economic and political hegemony in Ethiopia. The British Morning Post denounced Japan's machination in Africa. However, there were only 34 Japanese living in Ethiopia in 1934 (Hideko Faerber Ishihara 1998)! Nevertheless when Mussolini launched the Italian aggression, he mentioned the "yellow peril" which surrounded Ethiopia.

1 The Italian takeover of Ethiopia led to popular reactions in Japan where an armed response was mooted in discussions. However "realpolitik" prevailed.

The Italian takeover of Ethiopia led to popular reactions in Japan where an armed response was mooted in discussions. However "realpolitik" prevailed. The Japanese government chose to stay neutral and did not send arms to Ethiopia. In 1936, as Rome recognised Mandchuko (Manchuria) as a Japanese colony, Tokyo recognized Italy's control of Ethiopia.

\section{Tokyo consensus?}

In 1985, the Prime Minister of Malaysia launched its "Look East Policy" and some years later, the Indian government adopted the same principle. In 2005, in a speech given for the 25th anniversary of Zimbabwe independence, President Robert Mugabe advocated [for Zimbabwe] "to look East where the sun rises and to turn its back to West when the sun sets". Mugabe's sulphurous personality should not hide the significance of his message. This is not the first time that Africa looked east for a model. Today's Western critique against the appeal of the Beijing consensus in Africa may be considered as a distant echo of the fear raised by the appeal for the Japanese model.

The emergence of Japan in the $19^{\text {th }}$ century had marked the imagination of several colonized countries and the Japanese victory over Russia had strong repercussions in these countries. Thus in Bengal, a newspaper celebrated the humiliation of the Occident (West) and in Burma they called for the establishment of a Co-Prosperity Sphere around Japan. In Africa the emergence of Japan inspired policy makers in Madagascar and in Ethiopia. 
Boylyo Baenga (1992) described the fascination exercised by Japan on Malagasy elites at the end of the $19^{\text {th }}$ century. Nationalist sentiment against French colonial rule had emerged among a small group of Merina intellectuals who had been educated by Europeans and exposed to Western intellectual thought. The group was led by a Protestant clergyman, Pastor Ravelojoana, who was especially inspired by the Japanese model of modernisation. In 1912, he wrote: "To know that a non-European people living in a far away, a people in love with progress has been able to succeed a true revolution based on European knowledge, has moved me deeply". For Ravelojoana, while the French Revolution had brought the Declaration of the Rights of Man and of the Citizen, the Meiji revolution of 1868 brought to the world the universal route to break from absolute poverty. One year later, he established a secret society dedicated to Malagasy cultural identity which called itself Iron and Stone Ramification (Vy Vato Sakelika--VVS). On Christmas day in 1915, Ravelojoana was arrested by the colonial authorities. Together with 300 young followers of the Japanese model, Ravelojoana was tried and sentenced to spend the rest of his days in jail. Although the VVS was brutally suppressed, its actions eventually led French authorities to provide the Malagasy with their first representative voice in government.

\section{Ethiopia, reformers whose influence peaked in the 1920's and 1930's were called "Progressive Intellectuals", "Young Ethiopians" and "Japanizers".}

In Ethiopia, reformers whose influence peaked in the 1920's and 1930's, were called "Progressive Intellectuals", "Young Ethiopians" and "Japanizers" : each of these appellation emphasized something different: the need to reform, the need to find an appropriate model for reform and the impact of Japan's transformation from a feudal society-like Ethiopia's-into an industrial power. For these young educated Ethiopians, Japanization was a means to an end-to solve the problem of underdevelopment. One year after his signing of the Friendship treaty, the government promulgated a constitution closely modelled on Japan's Meiji Constitution of 1889. The same year the Foreign Minister Heruy Welde Sellase went to Japan to seek commercial and political ties as well as military aid. He spent one month there and on returning to his country, he wrote a book published in Amharic - "The Source of Light' - which introduced Japan to Africans. This publication played into western fears that Ethiopia would take Japan for its model for modernization.

\section{Conclusions}

A significant share of Japanese exports, 7 per cent in the late 1930s (Figure 1), were directed to Africa before World War II which interrupted these trade relations. The links that had been created before the war explain the rapid resurgence of Japanese exports to Africa in the late 1940s. In the 1950s, Japanese were able to regain market share in Africa and up to the mid-1950s, and, at the time, it traded more with Africa than with the European core (France, Germany, Benelux, Netherlands and Italy)! Japanese share of Sub-Saharan African trade reached a maximum in the 1960s but then it diminished. This Asian rise in Africa was succeeded by South Korea, whose trade share increased up to 2000, and China's share which shot up after 2000.

Chinese irruption in Africa caused the same critics as did Japan in the 1930s, and it was also accompanied by the same propagation of (unfounded) rumours concerning land grabbing! Historical comparisons are "false friends" and, generally speaking the lessons one can draw from them are not particularly convincing. Indeed, the only truth they bring is that men rarely heed the lessons from history. 


\section{End Notes}

${ }^{1}$ Source http://hansard.millbanksystems.com

${ }^{2}$ A few years after Marco Polo, Ibn Batouta travelled from Morocco to China along the Silk's Road.

${ }^{3}$ J Morikawa (1997) : Japan and Africa : big business and diplomacy London : Hurst, $\underline{1997}$

${ }^{4} \mathrm{Mr} \mathrm{Rem}$ : "A further question, is he aware that quite recently the Japanese traders were dumping motor cars into South Africa with British names and that the South African Government acted promptly and quickly?" House of Commons January 31,1934 http://hansard.millbanksystems.com

${ }^{5}$ Cotton thread and fabric represented $40 \%$ of Ethiopian imports in 1933 (Le Temps 5 November 1933),

${ }^{6}$ While the bulk of Japanese migrants had settled in Japanese colonies (Korea, Taiwan) and in Manchuria, their number had risen rapidly in Brazil and by 1934, there were 134000 Japanese of which a significant proportion engaged in the cultivation of cotton (Far Eastern Survey 1937 : Brazil cotton and Japanese migration vol $6 n^{\circ} 417$ February).

${ }^{7}$ Le Temps : L'Italie et l'Abyssinie, 18 December 1933

\section{References}

Ampiah, Kweku. 1990. "British commercial policies against Japanese expansionism in East and West Africa" 1932-35 The International Journal of African Historical Studies, $23,4$.

Ayinde, Aremu Fatai. 2009. A comparative study of Japan and China diplomacy in the contemporary historical context. Ritusmeikan: Asia Pacific University

Baenga, Boylo. 1992. L'Afrique en kimono. Editions Nouvelles du Sud

Bradshaw, Richard \& Ransdel, Jim. 2011. "Japan, Britain and the Yellow peril in Africa in the 1930s" The Asia Pacific Journal. Vol 9 issue $44 n^{\circ} 2$ October 31.

Calvitt Clarke III, J. 2000. Mutual interest? Japan and Ethiopia before the ItaloEthiopian war 1935-36 Jacksonville University. Annual Meeting of the Florida Conference of Historians: Orlando.

Calvitt Clarke III, J. 2007, Ethiopia's non-western model for westernization : foreign minister Heruy's mission to Japan, 1931 Paper presented to ISA South Jacksonville University.

Calvitt Clarke III, J. 2009: A Japanese scoundrel's skin game : Japanese economic penetration of Ethiopia and diplomatic complications before the second Italo-Ethiopian War in proceedings of the 16th international Conference of Ethiopian studies ed by Svein Ege Harald Aspen, Birhanu Teferra and Shiferaw Bekele, Trondheim

Etemad, Bouda \& Lützelschwab, Claude. 2005. Geographical structure of Africa's foreign trade from colonisation to independence, Swiss National Science Foundation; School of Oriental and African Studies: University of Neuchâtel. October 2005

Faerber-Ishihara, Hideko.1998. Les premiers contacts entre l'Ethiopie et le Japon Araesae Paris 
Kitagawa, Katsuhiko. 1990. "Japan's economic relations with Africa between the wars : a study of Japanese consular reports" African Study Monographs 11 (3), 125141 Décember.

Morikawa, J. 1997. Japan and Africa : big business and diplomacy London: Hurst, 1997

Olu, Agbi. 1992. Japanese relations with Africa. Ibadan University Press

Shionoya, Y., Yamazawa, I. 1973 "Industrial growth and foreign trade in Japan" in Economic growth, the Japanese Experience since the Meiji Era Vol 2, ed K. Ohkawa and Y Hayami Tokyo Japan Economic Research Centre

Jean Raphaël Chaponnière is an associate research fellow at the Asia Centre, Paris. He graduated from Supelec, and was, respectively, researcher at the National Center for Scientific Research (1980-1998), visiting research fellow at ISEAS (Singapore) and Euro Asia Institute (INSEAD), expert at the NESDB (Thailand); Economic counsellor in the French embassy in South Korea (1998-2000) and in Turkey (2000-2003) and senior economist at the Asian department of Agence Française de Développement

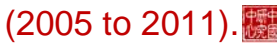

